islands of the globe, their composition, and their relations to one another, and to those of previous geological epochs. $\mathrm{He}$ then discusses the views of botanists respecting their origin and distinctive characters, and availing himself of such of their hypotheses as he thinks tenable, correlates these with those of palæontologists, and arrives at the conclusion "That the northern hemisphere has always played the most important part in the evolution and distribition of new vegetable types, or in other words, that a greater number of plants has migrated from north to south than in the reversed direction, and that all the great assemblages of plants which we call floras, seem to admit of being traced back at some time in their history to the northern hemisphere." This amount of accordance between the results of naturalists working wholly independently, from entirely different standpoints, and employing almost opposite methods, camnot but be considered as very satisfactory. I will conclude by observing that there is a certain analogy between two very salient points which are well brought out by these authors respectively. Count Saporta, looking to the past, makes it appear that the fact of the several floras which have flourished on the globe being successively both more localised and more specialised, is in harmony with the conditions to which it is assumed our globe has been successively subjected. $\mathrm{Mr}$. Dyer, looking to the present, makes it appear that the several floras now existing on the globe, are in point of affinity and specialisation, in harmony with the conditions to which they must have been subjected during recent geological time on continents and jislands with the configuration of those of our globe.

(To be continued.)

\section{HAECKEL ON THE LIBERTY OF SCIENCE AND OF TEACHING ${ }^{2}$}

PROF. HAECKEL has recently published his reply to the address on "The Liberty of Science in the Modern State," delivered at last year's meeting of the German Association, by Prof. Virchow. If we enter into this subject at greater length than is our custom with pamphlets we do so mainly from a sense of common fairness to both parties, since we reproduced Prof. Virchow's address in extenso (NATURE, vol. xvii. pp. 72, $7^{2}$, and $\left.I I I\right)$. We shall, however, confine ourselves merely to wating Prof. Haeckel's views on the subject, and leave it to our readers to judge of the value of his remarks for themselves.

In the preface to the little book before is Prof. Haeckel states that the general views developed by Virchow are in such comriete contrast to his own that no reconciliation of the two is $n$.ssible. Yet he refrained for a considerable time from publishing his reply; and this for two reasons. On the one hand, he thought he might safely leave the judgment of the strife between them to the future; first, because the evolution theory, which Virchow attacks, has, de facto, become the basis of bio. logical science of the present day; secondly, because Virchow's objections to the theory of descent have been so frequently and thoroughly refuted that it seemed superfluous to refute them again. On the other hand, he felt great reluctance in opposing a man whom a quarter of a century ago he honoured as the reforner of medical science, and whose pupil and zealous admirer be was for many years.

"The more I for years regretted Virchow's position as the enemy of our new evolution theory, and the more I was challenged to reply by his repeated attacks upon it, the less inclination I felt, nevertheless, to appear publicly as the anta. conist of the highly.honoured and meritorious man. If now I find myself forced to reply, I do so with the conviction that longer silence would only augment the erroneous views which my resignation hitherto has already produced. . . . I I must point out distinctly that it is not Virchow but I who am the person attacked, and that in my case there is no question of attacking a formerly highly-honoured friend, but of defending myself by necessity against his repeated and violent attacks. Another reason which compels me to speak at last lies in the continued fertile use made of Virchow's speech by all cierical and reactionary organs for the last nine months. . . . Already Friedrich von Hell wald has pointed out the great danger which ies in the fact that it was a Virchow who, under the banner of political Liberalism, and wrapped in the mantle of pure science, combated the liberty of science and of its teaching."

The author then continues to point out that the danger was

1 Freie Wissenschaft und freje Lehre. Fine Entgegnung auf Rudolf Virchow"s Münchener Rede uiber "die Freiheit der Wissenschaft im modernen Staat." Von Ernst Haeckel. never so great in Germany as at the present moment, where the political and religious life of the German nation seems to ap. proach a profound reaction. The two mad attempts upon the life of the honoured and aged Emperor have called fortb a storm of just indignation of such violence that even many Liberal politicians not only press for severe measures against the utopian teachings of social democracy, but, far overshooting the mark, demand that free thought and free teaching should be confined within the narrowest bounds. What more welcome support can the reactionary party wish for than that a Virchow should publicly demand the suppression of the liberty of science? The danger appears still greater to Prof. Haeckel if Virchow's great influence as a "liberal Progressist" is taken into consideration, now that the Prussian Diet will shortly open its debates on the educational law. "What," Prof. Haeckel asks, "may we expect of this edncational law, if in the discus. sions Virchow, as one of the few anthorities who will be constulted, raises his voice in favour of the principles which in his Munich speech he proclaimed as the safest guarantees for the liberty of science in the modern state. Article 20 of the Prassian Constitution, and $\S \mathbf{1 5}_{5}$ of that of the German Empire say: Science and its teachings are free. Virchow's first action, according to his present principles, must be a proposal to cancel this paragraph. In view of the menacing clanger, I cannot hesitate any longer with my reply. Amicus Socrates, amicus Plato, magis amica veritas!" The rest of the preface is concerned with a refutation of the "denunciation" by which Virchow wants to make the theory of descent responsible for the horrors of the Paris Commune. Haeckel thinks that by an intentional coupling of Darwinism with Social democracy, Virchow intended to do considerable damage to the former, indeed he sees in it an attempt to remove all "Darwinists" from their Academical chairs. At the same time he points out that nine out of every ten zoologists and botanists now teaching at European universities are Darwinists. Virchow's attempt is therefore perfectly futile, and will certainly never have any eftect at Jena. "What the Wartburg was for Martin Luther, what Weimar was for the greatest heroes of German literature, what Jena has been during three centuries for a large number of scientific men, that will Jena continue to be for the evolution-theory of the present day, as well as for all other scientific theories. which develop freely, viz., a firm stronghold for free thought free research, and free teaching."

We now come to the first chapter, which is headed "Evolution and Creation." The author remarks at the beginning that nothing has so greatly facilitated the progress of the evolution theory, as the fact that its principal problem, the question of the origin of species, was placed before the alternative: Either organisms have been deviloped naturally; in which case they must descend from the simplest and common ancestral formaor this is not the case, and the different species of organisms have originated independently of one another, in which case they can only have been created in a supernatural way, i.e., by a miracle. Natural development or supernatural creation of species-the choice must here be made, since a third way does not exist. Since Virchow and many other antagonists of the evolution theory constantly mix this up with the theory of descent, and this again with the theory of natural selection or Darwinism, Prof. Haeckel does not think it superfluous to give a concise definition of each of the three great theories at starting. $\mathrm{He}$ then states his definitions as follows:- "The relation of these theories according to the present state of science is therefore simply the following:-I. Monism, the universal theory of evolution, or the monistic pro-genesis theory, is the only scien. tific theory, which rationally explains the universe and satisfies the desire for causality in the human mind, since it brings all natural phenomena into a mecranical causal connection as parts of a great and uniform (einheitlich) process of development; II. Transformism, or the theory of descent, is an essential and indispensable part of the monistic evolution theory, because it is the only scientific theory which explains the origin of organic species in a rational manner, viz., by transformation, and reduces this transformation to mechanical causes; III. The theory of selection, or Darwinism, is up to the present the most important one amongst the different theories, which try to explain the transformation of species by mechanical causes ; but it is by no means the only one. Even if we suppose that most species have originated throngh natural selection, yet we know, on the other hand, that many forms called species are merely hybrids from two different species and are propagated as such; at the same time we 
can easily conceive that other causes may be acting in the formation of species, causes of which we have no idea at present. To decide what importance natural selection has in the origin of species is left to the judgment of the various naturalists, and in this question the authorities differ materially even to-day. Some ascribe a greater, others, a smaller im. portance to it. But the different estimation of the value of Darwinism is quite independent of the absolute validity of the theory of descent, because the latter is up to the present the only theory which explains, in a rational way, the origin of species. If we abandon this theory then nothing remains but the irrational supposition of a miracle, of a supernatural 'creation.' We will briefly designate this mystical belief in a creation as ' creatism.' In this decisive and inexorable alternative Virchow has now publicly stated his belief in creatism and his disbelief in transformism." The author then dwells at some length on this, and quotes from the Zeitschrift für Ethnologie, edited by Virchow and Prof. Bastian, in which the lattter applauds Virchow's Munich address, and ridicules Haeckel's "deliramenta and absurdities." There is no doubt, therefore, that Virchow bas confessed himself a "dualist and creatist," and is as convinced of the truth of his principles as Haeckel is of the con. trary as a "monist and transformist," yet the former still refrains from acknowledging his principles in all their consequences. "On the contrary he still clothes his opposition in the favourite phrase of the clerical papers, viz., that the theory of descent is an 'unproved hypothesis.' It is perfectly clear, however, that this theory will never be 'proved' if the proofs in existence to day are not considered sufficient. How often has it been repeated that the scientific certainty of the theory of descent is not based upon this or that single experience, but upon the totality of biological phenomena, upon the Caz/sal-nexus of evolution? What are we to think, therefore, of the new proofs for the theory of descent which Virchow demands?"

In Chapter II. Haeckel undertakes to give some "certain proofs of the theory of descent." He shows that all general phenomena of morphology and physiology, of chorology and oecology, of ontogeny and palæontology, can only be explained by the theory of descent, and reduced to mechanical causes. The guarantee of the truth of the theory lies particularly in the fact that the last simple causes are the same for all these complicated phenomena, and that other mechanical causes cannot be imagined. "Where are we, therefore, to find still further proofs for the truth of the theory of descent? Neither Virchow nor any other of the clerical antagonists or dualistic philosophers show us where we possibly might have to look for further proofs. Where in the world are we to find 'facts' which speak louder than the facts of comparative morphology and physiology, the facts of rudimentary organs and of embryonal development, than the facts of palreontology and of the geographical distribution of organisms-in short, than all the known facts from the most various biological domains?" If proofs by actual experiments are demanded, these proofs have also been furnished by the domestication of animals and plants, and their variations under such domestication. All working naturalists are perfectly well aware to-day that the morphological value of the word "species" is not an absolute but a relative one; nor has it any physiological value. Haeckel points out here that the class of animals which furnish the best "certain proof" that the conception of species has only a relative value, are the sponges: "their liquid form wavers to and fro with extra. ordinary uncertainty and variability, and makes all distinction of species quite illusory." The species question, one of the principal points in the theory of descent, is not even mentioned by Virchow, and Haeckel considers this bighly characteristic. He arrives at the conclusion that Virchow has never thoroughly digested the evolntion theory, and has never attentively studied Darwin's principal work on the Origin of Species, nor any other work by this author. The remainder of this chapter is devoted to an account of Virchow's activity, first at Würzburg, and afterwards at Berlin. Virchow left Würzburg for Berlin in 1856 ; it was at the former university that he made the celebrated application of the cell-theory to pathology, which caused quite a revolution in the latter science. Haeckel considers that the exchange of the narrow sphere for the wider one was not bene. ficial in its consequences, and that the Virchow of the present day has completely changed from the Virchow of 1848-1856; he points out that only those who are aware of the enormous progress morphology has made during the last twenty years, and have followed this science in all its details, can estimate the full value of the theory of descent, and of Darwin's theory of selection. "Whoever wishes to convince himself of what an enormous revolution was caused by these theories, in comparative anatomy particularly, let him compare the classical 'Grundziige der vergleichenden Anatomie' of Carl Gegenbaur (1870) and his 'Grundriss' (1878) with the older books on this science. Of all the colossal progress of morphology Virchow has no idea, since he was ever a stranger to this domain. His great reforms in pathology lie in the domain of physiology, and particularly in that of cellular physiology. But during the last twenty years these two principal branches of biological research have separated more and more. The great Johannes Müller was the last biologist who could comprise the entire domain of organic natural research, and who acquired immortal merit in both branches alike. After Muiller's death (1858) the two halves fell apart. Physiology, as the special science of the functions of organisms, turned more and more towards the exact and experimental method. Morphology, on the other hand, as the science of the shapes and forms of animals and plants, could of course make but little use of this method; it was bound to have recourse to the evolution theory, and thus became essentially a historical natural science. It was just upon this historical and genetic method of morphology, in contrast with the exact and experimental method of physiology, that I laid a particular stress in my Munich address. If Virchow, in his counter adclress, had really refuted the latter in its various details, instead of fighting it with phrases and denunciations, this contrast of principles would at least have been worth minute examination. Yet I do not wish to reproach Virchow with this, since he is completely involved in the onesided views of the school-physiology of the present day, and because morphology lies far too widely apart from his domain, to make it possible for him to judge its methods and ends for himself. If, nevertheless, upon every occasion he pronounces a depreciatory judgment upon it, then we must question his competence in doing this. It is true that in his Munich speech he prints with large type the phrase, "That which adorns me is the knowledge of my ignorance.' But I regret that I must deny him this adornment most completely. Virchow does not linow how ignorant he is of morphology. Otherwise he would not have pronounced those crushing sentences regarding it; he would not constantly designate the theory of descent as 'a hobby,' or 'dreaming; or as personal speculation, which now inflates itself on many domains of natural science.' Indeed Virchow honours 'me too much if he calls that my 'personal hobby' which for more than a decade has become the most valuable common property of morphological science, If Virchow were not so unacquainted with morphological literature he would know that it is already completely impregnated with the principle of descent; that in all morphological work which is carried on systematically and with a certain end in view, the theory of descent is now accepted as quite indispen. sable. But he is unaware of all this, and thus we understand why he continues to ask for 'certain proofs' for that theory when these proofs have in reality been furnished long ago."

Chapter III. treats of craniology as applied to the theory of the descent of man from the ape. Haeckel points out the importance of comparative and genetic craniology, but cannot help regretting that a great deal of time and labour has been wasted during the last ten years by "craniologists" with discussions as to the best method of measuring skulls, and also that numerous naturalists, Virchow among others, seem to have seen in "cranjometry" the highest aim and object of craniological science, and to have forgotten what they really want to prove with their measurements. Turning to the question of the descent of man, the author remarks that the well-known phrase "man has descended from the ape," which is so often misuncierstood and misapplied, can in the sense of the evolution theory but have this meaning: The human race as a whole has descended from the order of apes, i.e., from one (or perhaps more) species of apes now long extinct; the latest ones in the long series of man's vertebrate ancestors were apes or ape-like animals. Of course none of thespecies of apes now existing can be regarded as the unchanged descendant of the old parental form. Virchow in his address expresses his doubt of the truth of the descent in question, while Haeckel looks upon it as one of the most certain phylogenetic hypotheses. He does not deny that the relative certainty of this as well as that of any other phylogenetic hypothesis cannot be compared to the absolute certainty of the theory of descent, and draws specia ? attention to the great difference between the whole theory and any particular hypothesis relating to an individual order or class 
of animals; such hypotheses are always dependent on our actual biological knowledge and may be changed at any time for better ones, while the theory as a whole needs no further proof; it is absolutely certain. But for the objective zoologist it is im. possible, according to the principles of comparative systematics, to assign to man any other place in the animal kingdom than in the order of apes, or primates, as Linnæus calls them; this classification, which is inevitable, leads to the common descent of man and ape from one ancestral form; and this is the essential part of the question. The views as to the exact appearance of this ancestral form may be divided, but we must eventually arrive at the conclusion, if we consider all facts connected with the subject, that our long extinct ancestors can but have been real apes, i.e., some placental mammal, which, if it existed to-day, we should certainly classify among apes. Finally, Haeckel points out how characteristic it is of Virchow's view on the matter that he again places palreontology into the foreground, and, before accepting the theory of descent, demands that an uninterrupted series of fossil transition forms between ape and man should first be found. As Darwin himself has minutely stated the reasons why the solution of this problem cannot be expected, and has shown the cause of the extraordinary incompleteness of the palæontological records, and of the natural impediments to a geological proof of the ancestral tree (in Chapter X. of the "Origin of Species"), Haeckel again arrives at the conclusion that Virchow has never attentively read Darwin's great work, and has never cligested the teachings of palarontology.

Chapter IV. is entitled "Cell-Soul and Cellular Psychology." Haeckel states here that the views he expressed at Munich with regard to the soul of the cell, i.e., "that we must indeed ascribe an independent sonl-life to each organic cell," are but the natural consequence of Virchow's own teach. ings, viz., of the very fertile application which Virchow made of the cell theory to pathology. He then proceeds to give the definition of the word "soul" according to both philosophical theories, first according to the monistic or realistic theory, and then according to the dualistic or spiritualistic theory ; he compares the simplicity of the former with the mystery and irra. tionality of the other. $\mathrm{He}$ adduces the various phrases in Virchow's address which leave no doubt on the subject that Viichow has completely abandoned the realistic theory in favour of the dualistic one, and shows the utter futility of Virchow's view that we cannot find psychic phenomena in the lower animals. "Volition and sensation, the most general and most indubitable qualities of all mental life, cannot be overlooked in the lower animals. Indeed, with most Infusoria, particularly with Ciliata, independent motion and conscious sensation (of pressure, heat, light, \&c.) are so very evident, that one of their most patient observers, Ehrenberg, maintained up to his death that all Infusoria must have nerves and muscles, organs of sense and of mind (Seelenorgane) just like all higher animals.

"Now it is known that the enormous progress which science has recently made in the natural history of these low organisms has reached its climax in the maxim that they are unicelluslar (a maxim which Siebold pronounced thirty years ago, but which has been proved with certainty only recently); therefore in the Infusoria a single cell performs all the different functions of life, including the mental functions, which in the Hydrce and Spongie are divided amongst the cells of the two germinal lobes, and in all higher animals amongst those of the various tissues, organs, and apparatus of a complicated organism. ... By the same right by which we ascribe an independent 'soul' to these unicellular Infusoria, we must ascribe one to all other cells, because their most important active substance, the protoplasm, shows everywhere the same psychic properties of sensitiveness (sensation) and movability (volition). The difference in the higher orga. nisms is only that there the numerous single cells give up their individual indefendence, and like good state-citizens, subordinate themselves to the 'state-soul' which represents the unity of will and sensation in the 'cell-association.' We must distinguish between the central soul of the total polycellular organism or the 'personal soul' and the separate elementary souls of the single cells, or 'cell-souls.' This maxim is excellently illustrated by the interesting group of Siphonophora. There is no doubt that the whole Siphonophora-state has a very determined and uniform (einheitlich) will and sensation; yet each one of the single individuals which compose this state (or Cormus) has its separate personal will and sensation. Indeed each one of these is originally a separate Medusa and the 'individual' Siphono- fhorc-state has resulted only by association and division of labour of this united society of Medusce. Next to the unicellular Infusoriz no phenomenon affords such ample and immediate proof for the truth of our cellular-psychology than the fact that the human ovum, ilke the ovum of all other animals, is a simple and single cell. According to our monistic conception of the cell-soul, we must suppose that the fertilised ovum already possesses virtually those psychic properties which in the particular mixture of parental peculiarities (i.e., those of mother and father) characterise the individual sonl of the new being. In the course of the development of the ovum the cell. soul of conrse developes itself simultaneously with its material substratum, and becomes apparent actually when the child is born. According to Virchow's dualistic conception of the 'Psyche,' we must suppose, on the contrary, that this immaterial being enters the soulless germ at some period of embryonal development (perhaps when the spinal tube separates from the germinal lobe?). Of course this way the pure miracle is complete, and the natural and uninterrupted continuty of developinent is superftuous."

( To be continued.)

\section{UNIVERSITY AND EDUCATIONAL INTELLIGENCE}

St, Peter's College, CAMbridge, has made a statute assign ing one of its Fellowships to the Jacksonian Professor. It is intended to limit this professorship by statute to some branch or branches of chemistry or physics, a specially cunstituted electoral body, including representatives of non-resident science, making the selection freely on each occasion of a vacancy.

THE site most favoured for the Sedgwick Memorial Museum, Cambridge, is Downing Street, in front of the present new museums. There will be a good opportunity of concealing from public view these extremely plain buildings and of erecting a satisfactory facade. The Sedgwick Committee have informed the University that $\mathrm{x}, 2002$. is in their hands for this purpose, but this amount is insufficient, and the University, when better supplied with funds, must supply a good deal more. A Syndicate, including Drs. Paget and Humphry, Profs. Liveing, Newton, Hughes, and Colvin, has just been appointed to select a site, to obtain plans, to confer with the Sedgwick Committee, and report by midsummer next.

Prof. Leith Adams, F.R.S., has been appointed to the Chair of Natural History in the Queen's University of Ireland, rendered vacant by the lamented death of Prof. Harkness.

\section{SOCIETIES AND ACADEMIES LONDON}

Royal Society, November 21.- "On a Method of Using the Balance with great Delicacy, and its Employment to Determine the Mean Density of the Earth," by J. H. Poynting, B.A., Fellow of Trinity College, Cambridge, and Demonstrator in the Physical Laboratory, Owens College. Communicated by Prof. Balfour Stewart, LL.D., F.R.S.

The two chief causes of error in the use of the balance are :I. Disturbances through changes of temperature, such as con vection currents, or unequal expansion of the two arms. 2. The possibility that after raising the beam on the supporting frame and lowering it again, the same parts of the knife edges, may not come into contact with the planes. Errors from the first cause may be to a great extent avoided by protecting the balance with a gilded case, and reading the oscillations from a distance by means of a mirror on the beam. The residual effects may then be detected by taking three observations at equal intervals of time, the first and third having the same weights in the pan, and their mean being compared with the second (i.e., for a short time the disturbance is assumed to be a linear function of the time). The second cause of error has been removed by not raising the beam between successive weighings. For this purpose a clamp is placed underneath one pan, which can be brought into action at any time to fix the pan in whatever position it may be. The weights can then be interchanged while the counterpoise (Borda's method being employed) maintains the beam in the same state of flexure, and the knife edges always remain in contact with the same parts of the planes.

The value of a given deflection was estimated by riders, and the weights were interchanged each by special arrangements. 